\title{
EFEKTIFITAS PEMBINAAN MADRASAH DINIYAH DI KOTA YOGYAKARTA
}

\author{
Abd. Muin M \\ Peneliti Puslitbang Pendidikan Agama dan Keagamaan \\ Balitbang dan Diklat Kementerian Agama RI \\ Jl. MH. Thamrin No. 6 Jakarta Pusat \\ Email: abd.muinfikri@yahoo.com
}

\begin{abstract}
The issue in this research is the effectiveness of coaching committed by the Ministry of Religion of Yogyakarta to improve teaching skills of madrasah diniyah teachers. To that end, this study aims to describe the effectiveness of coaching to improve madrasah diniyah teachers' skills and abilities. This study uses descriptive qualitative method with primary data collection through focus group discussions (FGDs), in-depth interviews, and observation while secondary is data obtained through documentation. The study showed that the Ministry of Religious Yogyakarta City officials have not been effective to guide the improvement of capabilities of madrasah diniyah teachers' teaching skills because the Ministry of Religious Affairs has not programmed ability and teaching skills development of teachers with adequate budget.
\end{abstract}

Keywords: effectiveness, coaching, teacher, madrasah diniyah.

\begin{abstract}
Abstrak
Permasalahan dalam penelitian ini adalah bagaimana tingkat efektifitas pembinaan yang dilakukan aparat Kementerian Agama Kota Yogyakarta untuk meningkatkan kemampuan dan keterampilan mengajar guru madrasah diniyah? Untuk itu, penelitian ini bertujuan mendeskripsikan tingkat efektifitas pembinaan untuk meningkatkan kemampuan dan keterampilan mengajar guru madrasah diniyah. Penelitian ini menggunakan metode kualitatif deskriptif dengan teknik pengumpulan data primer melalui focus group discussion (FGD), wawancara mendalam, dan observasi. Sedangkan data sekunder diperoleh melalui studi dokumentasi. Temuan penelitian menunjukkan bahwa aparat Kementerian Agama Kota Yogyakarta belum efektif melakukan pembinaan terhadap peningkatan kemampuan dan keterampilan mengajar guru madrasah diniyah. Hal ini disebabkan karena Kementerian Agama belum memogramkan pembinaan kemampuan dan keterampilan mengajar guru dengan anggaran yang memadai.
\end{abstract}

Kata Kunci: efektifitas, pembinaan, guru, madrasah diniyah.

\section{PENDAHULUAN}

Madrasah diniyah sebagai pendidikan keagamaan Islam, umumnya diselenggarakan oleh masyarakat sebagai perwujudan pendidikan dari, oleh dan untuk masyarakat. Karena itu, keberadaan madrasah diniyah berbasis masyarakat menjadi sangat penting dan strategis, terutama karena bersumber dari aspirasi masyarakat dan sekaligus mencerminkan kebutuhan masyarakat yang sesungguhnya terhadap jenis layanan pendidikan.

Madrasah diniyah sebagai bentuk pendidikan keagamaan Islam secara kelembagaan mengalami pertumbuhan dan perkembangan yang pesat sebagai akibat adanya dugaan masyarakat bahwa pendidikan agama

Naskah diterima 27 Oktober 2014. Revisi pertama, 21 November 2014. Revisi kedua, 25 November 2014 dan revisi terakhir 4 Desember 2014. 
Islam di sekolah (jalur pendidikan formal) dinilai mengalami berbagai keterbatasan. Karena itu, Peraturan Menteri Agama RI Nomor 13 Tahun 2014 tentang Pendidikan Agama Islam Pasal 1 ayat (1) menyebutkan Diniyah Takmiliyah yang selanjutnya disebut Madrasah Diniyah Takmiliyah adalah lembaga pendidikan keagamaan Islam pada jalur pendidikan nonformal yang diselenggarakan secara terstruktur dan berjenjang sebagai pelengkap pelaksanaan pendidikan agama Islam pada jenjang pendidikan dasar, menengah dan tinggi. Juga pada Pasal 46 ayat (1) menyebutkan bahwa pendidikan diniyah takmiliyah diselenggarakan untuk melengkapi, memperkaya dan memperdalam pendidikan agama Islam pada MI/SD, MTs/SMP, MA/SMA/ MAK/SMK dan pendidikan tinggi dalam rangka peningkatan keimanan dan ketaqwaan peserta didik kepada Allah SWT.

Oleh karena itu, madrasah diniyah takmiliyah berperan untuk memperkuat, melengkapi dan memperdalam pendidikan agama Islam pada jalur pendidikan formal, ternyata tidak hanya diselenggarakan dalam lingkungan pondok pesantren, tapi juga cukup banyak diselengggarakan oleh masyarakat di luar pondok pesantren seperti; di masjid, mushalla, rumah ustadz dan tempat-tempat lainnya yang dipandang layak. Madrasah diniyah, terutama yang diselenggarakan di luar lingkungan pondok pesantren cukup banyak diselenggarakan oleh tokoh-tokoh masyarakat yang tidak berlatar belakang pendidikan pondok pesantren (pendidikan keagamaan), mereka mendirikan madrasah diniyah takmiliyah dengan motivasi kuat untuk mendidik anak-anak melalui internalisasi nilai-nilai pendidikan agama yang secara terprogram, terstruktur dan terarah melalui pendidikan keagamaan nonformal (madrasah diniyah takmiliyah).

Begitupun, guru-guru (asatidz) di madrasah diniyah sebagian besar mereka tidak berlatar belakang ilmu pendidikan dan keguruan, misalnya; ilmu tarbiyah dan ilmu ta'dib, bahkan di antara guru-guru tersebut terdapat lulusan tingkat pendidikan menengah, khususnya guru pendidikan agama. Karena itu, jika guru-guru tersebut tidak memperoleh pembinaan profesi guru yang efektif, maka bagaimana mungkin mereka memiliki kemampuan dan keterampilan yang handal dalam proses pembelajaran.

Pendidikan diniyah (madrasah diniyah takmiliyah) merupakan bagian yang tidak terpisahkan dari pendidikan nasional. Dalam hal ini, sebagai komponen sistem pendidikan nasional seharusnya berhak memperoleh kesempatan untuk menikmati pembinaan dari pemerintah. Sedangkan pihak pemerintah, terutama Kementerian Agama berkewajiban memberikan layanan pembinaan yang efektif, sebagaimana pembinaan terhadap lembagalembaga pendidikan lainnya. Karena itu, apakah Kementerian Agama telah melakukan pembinaan yang efektif tehadap madrasah diniyah, khususnya pembinaan dalam peningkatan kemampuan dan keterampilan mengajar guru-guru madrasah diniyah?

Berdasarkan data ${ }^{1}$ Kanwail Kementerian Agama Provinsi Daerah Istimewa Yogyakarta tahun 2014 terdapat 304 madrasah diniyah baik yang diselenggarakan di lingkungan pondok pesantren maupun di luar pondok pesantren, misalnya di masjid, mushalla, rumah ustadz. Madrasah diniyah yang materi pembelajarannya berfokus kepada "pendidikan keagamaan" baik secara teori maupun peraktek (pembiasaan penanaman nilai-nilai ajaran Islam), jika dibina secara efektif, maka akan menjadi potensi yang sangat besar untuk memperkuat dan memperdalam pemahaman terhadap ajaran Islam sebagai "rahmatan lil'alamin" dalam berbagai aspek kehidupan.

Hasil penelitian Puslitbang Pendidikan Agama dan Keagamaan bekerjasama dengan IAIN Raden Fatah tahun 2003 tentang "Evaluasi Penyelenggaraan Pendidikan Keagamaan

${ }^{1}$ Sumber: Bidang Pendidikan Diniyah dan Pondok Pesantren Kantor Wilayah Kementerian Agama Provinsi Daerah Istimewa Yogyakarta, tahun 2014. 
Diniyah", antara lain menyimpulkan, bahwa pembinaan terhadap penyelenggaraan madrasah diniyah belum dilaksanakan dengan memadai. Juga Puslitbang Pendidikan Agama dan Keagamaan tahun 2005 melakukan penelitian tentang "Masyarakat Pendukung Madrasah Diniyah", antara lain hasilnya adalah umumnya pendukung penyelenggaraan madrasah diniyah adalah masyarakat yang terdiri dari latar pendidikan dasar dan menengah dengan status sosial ekonomi menengah ke bawah, tapi memiliki relegiutas yang kuat. Dari hasil penelitian ini dapat disimpulkan, bahwa jika pihak Kementerian Agama belum efektif melakukan pembinaan terhadap penyelenggaraan madrasah diniyah, maka bagaimana mungkin masyarakat pendukungnya melakukan pembinaan yang memadai, sebab mereka hanya berpendidikan dasar dan menangah, maka kapan kualitas pendidikan madrasah diniyah sebagai benteng aqidah dan pemelihara akhlaqul karimah bagi masyarakat dapat terwujud ? Karena itu, posisi penelitian ini untuk memperkuat atau menolak hasil penelitian sebelumnya.

Berdasarkan uraian di atas, dapat dirumuskanbahwa secara umum permasalahan penelitian ini (research problems) adalah bagaimana tingkat efektifitas pembinaan madrasah diniyah. Mengingat keterbatasan waktu, tenaga dan dana yang tersedia, peneliti membatasi permasalahan penelitian dengan fokus pada "Efektifitas Pembinaan Profesi Guru Madrasah Diniyah", khususnya tentang pembinaan terhadap "kemampuan dan keterampilan guru" dalam mengajar. Hal ini dirumuskan sebagai permasalahan penelitian dengan alasan, bahwa peningkatan kualitas komponen-komponen sistem pendidikan yang paling utama berpengaruh terhadap peningkatan kualitas pendidikan adalah komponen "guru/pendidik" (human resources), sebab komponen-komponen pendidikan lainnya, seperti kurikulum, sarana pendidikan (material reseorces) tidak dapat bermanfaat secara maksimal dalam proses pembelajaran, jika tidak didukung oleh adanya guru yang berkemampuan dan berketerampilan tinggi dalam mengajar.

Atas dasar fokus permasalahan penelitian di atas, secara umum penelitian ini bertujuan untuk mengungkapkan tingkat efektifitas pembinaan guru madrasah diniyah. Sedangkan secara khusus, penelitian ini bertujuan untuk mendekripsikan bagaimana tingkat efektifitas pembinaan kemampuan dan keterampilan guru madrasah diniyah dalam mengajar. Untuk itu, hasil penelitian ini dapat bermanfaat bagi Ditjen Pendidikan Islam, Direktorat Pendidikan Diniyah dan Pondok Pesantren Kementerian Agama, Kanwil Kementerian Agama Provinsi DI Yogyakarta dan Kepala Kantor Kementerian Agama Kab/Kota dalam menyusun dan menetapkan kebijakan pembinaan yang efektif terhadap peningkatan kemampuan dan keterampilan mengajar guru-guru madrasah diniyah.

\section{Kerangka Konseptual}

Pada dasarnya efektifitas dapat menunjukkan sampai di mana tingkat ketercapaian suatu tujuan yang telah ditetapkan. Menurut Goodall dan Culhane, efektifitas merupakan kondisi yang dapat mengandung suatu pengertian tentang terjadinya akibat yang diharapkan. ${ }^{2}$ Sejalan dengan ini, Prawirosentono mengemukakan bahwa efektifitas sangat berkaitan dengan masalah tentang bagaimana mencapai tujuan/hasil, bagaimana tingkat daya fungsi komponen suatu organisasi dan bagaimana mencapai tingkat kepuasan organisasi. ${ }^{3}$ Selain itu, menurut Armand efektifitas adalah adanya suatu konsistensi perbuatan yang kuat untuk

${ }^{2}$ Goodall M \& B Culhane. 1991. Teaching Strategies for a Clever Country. Australia: Association for the Gifted Talented, h. 205.

${ }^{3}$ Sujadi Prawirosentono. 1999. Kebijakan Kinerja Karyawan: Kiat Membangun Organisasi Kompetetif Menjelang Perdagangan Bebas Dunia. Yogyakarta: BPFE, h. 2 . 
mencapai suatu tujuan yang telah ditetapkan bersama. ${ }^{4}$

Dari berbagai konsep efektifitas di atas, dapat ditarik kesimpulkan bahwa efektifitas merupakan suatu ukuran yang menyatakan sampai di mana tingkat pencapaian tujuan atau target yang telah ditentukan terlebih dahulu.

Adapun pembinaan profesi guru, menurut Oemar adalah program yang secara terstruktur dan dapat mendorong terjadinya peningkatan profesionalisme guru. ${ }^{5}$ Seirama dengan pendapat ini, David mengemukakan bahwa pembinaan merupakan suatu proses, perbuatan dan tindakan yang dilakukan secara sengaja dan efektif untuk mencapai hasil yang lebih baik. ${ }^{6}$

Sehubungan dengan itu, guru sebagai jabatan profsi harus memiliki kemampuan dan keterampilan yang handal dalam proses pembelajaran. Dalam hal ini, menurut Danim kemampuan adalah perilaku yang rasional untuk mencapai tujuan yang dipersyaratkan sesuai dengan kondisi yang diharapkan. ${ }^{7}$ Sedangkan kemampuan berkaitan dengan profesi guru, Wijaya dan Rusyan mengemukakan, bahwa kemampuan dapat diterjemahkan sebagai suatu gambaran hakekat kualitatif dari perilaku guru yang nampak sangat berarti. ${ }^{8}$ Karena itu, suatu kemampuan dalam suatu profesi yang berbeda menuntut adanya kemampuan yang berbeda pula. Sedangkan kemampuan dalam profesi guru tampak dengan jelas pada kemampuan pengalaman dari kompetensi guru itu sendiri.

Apabila memperhatikan dengan cermat pengertian kemampuan tersebut, berarti setiap profesi yang diemban seseorang harus

${ }^{4}$ Armand, Feigenbaum. 1989. Total Quality Control. London: McGraw Hill, h. 183.

${ }^{5}$ Oemar Hamalik. 2009. Pendidikan Guru Berdasarkan Pendekatan Kompetensi. Jakarta: Bumi Aksara, 47.

${ }^{6}$ David A Garvin. 2000. Learning in Action. Boston: Harvard Business Press. h. 199.

${ }^{7}$ Sudarwan Danim. 1994. Tranformasi Sumber Daya Manusia. Jakarta: Bumi Aksara, h. 12.

${ }^{8}$ Wijaya dan Tabrani Rusyan. 1992. Profesionalisme Tenaga Kependidikan. Bandung: Nine Karya Jaya, h. 7. disertai dengan kemampuan, di mana profesi itu sendiri dibatasi sebagai suatu pekerjaan yang memerlukan pendidikan lanjut di dalam ilmu pengetahuan dan teknologi yang digunakan sebagai perangkat dasar untuk diimplementasikan dalam berbagai kegiatan yang bermanfaat. ${ }^{9}$

Kegiatan pembelajaran merupakan suatu proses yang kompleks dan melibatkan berbagai aspek yang saling berkaitan antara satu dengan lainnya. Karena itu, untuk mewujudkan proses pembelajaran yang berkualitas diperlukan berbagai keterampilan mengajar. Keterampilan mengajar merupakan kompetensi pedagogik yang cukup kompleks karena merupakan integrasi dari berbagai kompetensi guru secara utuh dan menyeluruh. Ini berarti, bahwa keterampilan mengajar guru merupakan seperangkat kecakapan guru dalam melatih dan membimbing berbagai aktivitas dan pengalaman santri serta membantunya untuk tumbuh dan berkembang secara wajar dan layak.

Uraian di atas, menujukkan bahwa efektifitas pembinaan kemampuan dan keterampilan mengajar guru-guru madrasah diniyah sangat penting dan strategis untuk lebih meningkatkan kualitas pendidikan di madrasah diniyah takmiliyah, sehingga lulusannya mampu memahami, menghayati dan mengamalkan secara mendalam nilai-nilai ajaran Islam dalam berabagai aspek kehidupan.

Dengan demikian, efektifitas pembinaan profesi guru dalam penelitian ini berkaitan dengan masalah seberapa jauh atau bagaimana tingkat ketercapaian tujuan aparat Kementerian Agama dalam menjalankan tugas danfungsinya secarakonsisten sebagai pembina profesi guru yang mampu memotivasi guru madrasah diniyah untuk lebih meningkatkan profesionelismenya sehingga efektif dapat memuaskan guru khususnya dan umumnya warga madrasah diniyah. Hal ini berarti, bahwa pembinaan kemampuan dan keterampilan guru

${ }^{9}$ AM Sardiman. 1996. Interaksi dan Motivasi Belajar Mengajar. Jakarta: Rajawali, h. 131. 
dalam mengajar yang dilakukan oleh aparat Kementerian Agama dapat dikategorikan efektif, jika pembinaan tersebut dilakukan secara konsisten sehingga dapat memuaskan guru-guru (asatidz) madrasah diniyah, karena dapat memiliki kemampuan dan keterampilan yang handal dalam menjalankan profesinya sebagai pengajar dan pendidik. Jika tidak, maka pembinaan tersebut dapat dikategorikan belum efektif.

\section{Metodologi Penelitian}

Di Daerah Istimewa Yogyakarta terdapat 304 madrasah diniyah yang tersebar pada 5 kabupaten/kota, yaitu: Kota Yogyakarta 28 (9,21\%), Kab. Kulon Progo 35 (11,51\%), Kab. Bantul 69 (22,70\%), Kab. Gunung Kidul 97 (31,91\%) dan Kab. Sleman 75 (24,67\%) madrasah diniyah. ${ }^{10}$ Peneliti menetapkan Kota Yogyakarta sebagai lokasi penelitian dengan asumsi, bahwa jumlah madrasah diniyah di Kota Yogyakarta jumlahnya lebih sedikit dibanding dengan daerah lainnya. Selain itu, lokasi dan lingkungan madrasah diniyah di Kota Yogyakarta umumnya relatif lebih mudah dijangkau dibanding dengan daerah lainnya. Hal ini sangat penting, sebab di antara faktor yang dapat mempengaruhi tingkat efektifitas suatu pekerjaan adalah masalah lokasi dan lingkungan. Karena itu, jika guru-guru madrasah diniyah di Kota Yogyakarta belum efektif mendapatkan pembinaan, maka patut diduga bahwa guru-guru madrasah diniyah di daerah lainnya (Kab. Kulon Progo, Kab. Kab. Bantul, Kab. Gunung Kidul dan Kab. Slemen) jauh lebih tidak efektif lagi mendapatkan pembinaan.

Di samping itu, jika aparat Kementerian Agama Kota Yogyakarta berhasil melakukan pembinaan kemampuan dan keterampilan guru-guru madrasah diniyah secara efektif,

${ }^{10}$ Sumber: Bidang Pendidikan Diniyah dan Pondok Pesantren Kantor Wilayah Kementerian Agama Provinsi Daerah Istimewa Yogyakarta, tahun 2014 (data diolah oleh Peneliti). berarti guru-guru madrasah diniyah telah mendapatkan pembinaan yang efektif. Ini menunjukkan, bahwa aparat Kementerian Agama dan guru-guru madrasah diniyah di Kota Yogyakarta dapat dijadikan contoh (studi banding) dari aparat Kementeria Agama dan guru-guru madrasah diniyah di Kab. Kulon Progo, Kab. Kab. Bantul, Kab. Gunung Kidul dan Kab. Slemen, mengingat secara geografis letak Kota Yogyakarta berada di tengah-tengah Provinsi DI Yogyakarta.

Penelitian ini menggunakan metode kualitatif dengan alasan, antara lain; Menurut Glaser penelitian kualitatif dilakukan karena sifat dan masalah penelitian itu sendiri menuntut untuk menggunakan metode kualitatif. Selainitu, penelitian bertujuan untuk mengungkapkan apa yang tersembunyi di balik fenomena yang sulit untuk diungkapkan dengan metode penelitian kuantitatif. ${ }^{11}$ Sejalan pendapat ini, Alwasilah mengemukakan: (a) metode kualitatif lebih memungkinkan peneliti mengidentifikasi berbagai realitas di lapangan, sehingga memungkinkan terjadi interaksi secara intens antara peneliti dengan informan yang lebih eksplisit dan mudah dilakukan. (b) tujuan penelitian ini lebih diwarnai oleh adanya interaksi di antara realitas. Karena itu, untuk memaknai kegiatan interaktif ini peneliti seyogiayanya berinteraksi secara langsung dengan para informan baik melalui wawancara maupun observasi dalam latar alamiah, sehingga dapat memperoleh pemahaman emik (menurut pendapat informan, bukan pendapat peneliti). ${ }^{12}$

Teknik pengumpulan data primer dilakukan melalui: (1) Focus group discussion yang dihadiri 29 orang, terdiri dari: 14 guru dan 13 kepala madrasah diniyah, 1 orang tokoh masyarakat, 1 orang Ketua Forum Komunikasi Diniyah Takmiliyah (FKDT) bertempat di Aula

${ }^{11}$ Barney Glaser \& Anselm L. Strauss. 1980. The Discovery of Grounded Theory. New York: Aldine Publishing Company, h. 72.

12 A. Chaedar Alwasilah. 2003. Pokoknya Kualitatif. Jakarta: Dunia Pustaka Jaya, h. 103-105. 
Kantor Kementerian Agama Kota Yogyakarta pada hari Jum'at 7 Maret 2014, (2) Wawancara mendalam dengan sejumlah narasumber kunci (key informan), yaitu, mereka yang terlibat secara langsung sesuai peran aktif yang dimilikinya. Jumlah narasumber, peneliti tidak membatasi jumlahnya, tapi sesuai kecukupan data/informasi yang diperlukan untuk menjawab permasalahan penelitian ini, (3) Observasi, bertujuan untuk mengetahui secara langsung (obyektif) bagaimana kemampuan dan keterampilan guru yang sedang mengajar. Kegiatan observasi dilakukan di Madrasah Diniyah Takmiliyah Al Qur'an 'Aisyiyah Jatimulyo, ini diselenggarakan di luar lingkungan pondok pesantren. Juga observasi dilaksanakan di Madrasah Diniyah Pondok Pesantren Al Barokah Karangwaru, ini diselenggarakan di lingkungan pondok pesantren. Sedangkan data sekunder ditelusuri melalui studi dokumentasi. Dalam penelitian kualitatif, peneliti sebagai instrumen utama. Namun, peneliti tetap menggunakan pedoman wawancara dan observasi. Hal ini dilakukan, agar peneliti bisa berempati, berinteraksi secara aktif dan dapat memahami perspektif informan.

Adapun pedoman observasi yang peneliti gunakan dalam mengobservasi proses pembelajaran yang dilakukan oleh guru madrasah diniyah, adalah model observasi menurut Flander dalam Gay, ${ }^{13}$ sebagai berikut:

${ }^{13}$ L. R. Gay. 1987. Educational Research:Competencies for Analysis and Application. Columbus: Marril Publishing Company, h. 108.

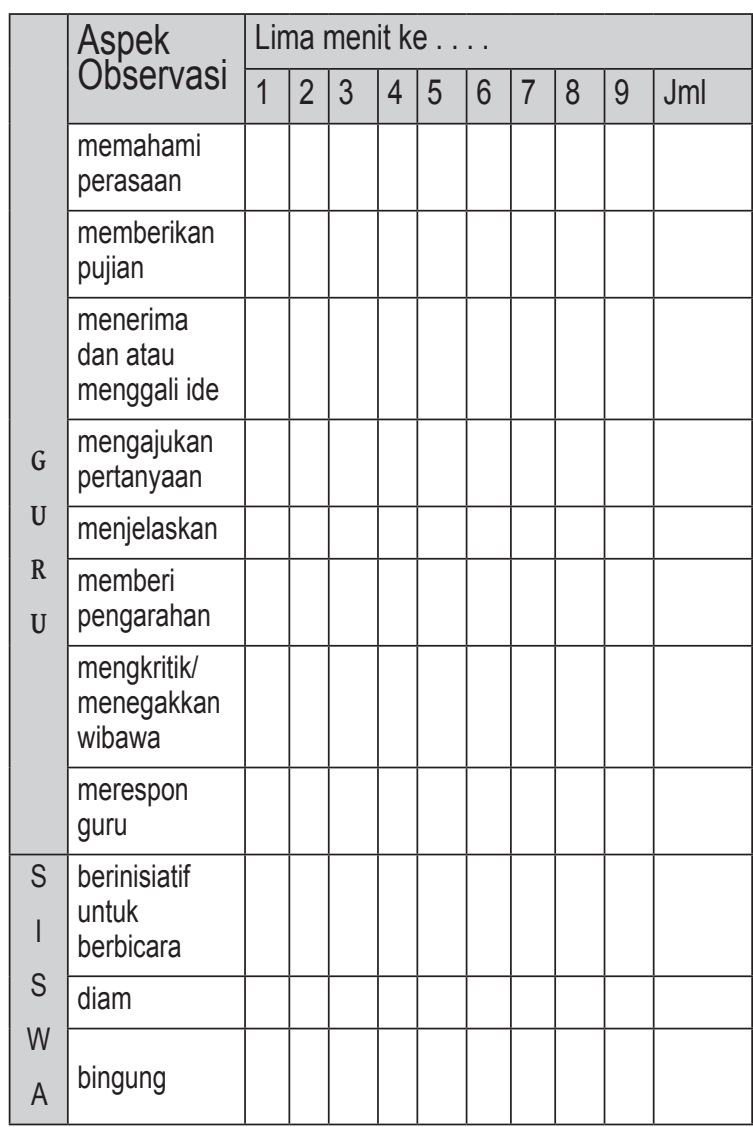

Untuk menetapkan keabsahan data, peneliti menggunakan kriteria: derajat kepercayaan (credibility), keteralihan (transferability), kebergantungan (dependability) dan kepastian (confirmability). ${ }^{14}$ Sedangkan teknik pemeriksaan keabsahan data peneliti melakukannya melalui: 1) Ketekunan observasi, menemukan ciri-ciri dan unsurunsur dalam sistuasi yang sangat relevan dengan persoalan atau issu yang sedang diteliti, kemudian peneliti memusatkan diri pada halhal tersebut secara rinci. ${ }^{15}$ 2) Triangulasi: (a) triangulasi sumber, peneliti membandingkan data/informasi hasil observasi dengan hasil wawancara, membandingkan apa yang dikatakan orang di depan umum dengan apa yang dikatakannya secara pribadi dan membandingkan hasil wawancara dengan isi dokumen yang berkaitan, dan (b) triangulasi

${ }^{14}$ Lexy J. Moleong. 2004. Metodologi Penelitian Kualitatif. Bandung: Remaja Rosdakarya, h. 324.

${ }^{15}$ Lexy J. Moleong. 2004. Ibid., h. 329. 
metode, peneliti melakukan pengecekan derajat kepercayaan beberapa sumber data/ informasi dengan metode yang sama. ${ }^{16}$

Pada dasarnya, analisis data kualitatif dilakukan ketika peneliti masih dalam proses pengumpulan data lapangan. Dalam hal ini, teknik analisis data yang digunakan oleh peneliti adalah teknik analisis data menurut Miles dan Huberman, terdiri dari: (1) reduksi data, (2) penyajian data, (3) menarik kesimpulan/verifikasi. ${ }^{17}$

Reduksi data, ini merupakan proses dalam pemilihan, pemusatan perhatian, pengabstraksian dan pentransformasikan data kasar yang diperoleh baik melalui obeservasi, wawancara maupun dokumen-dokumen terkait. Proses ini dilakukan peneliti selama penelitian berlangsung. Awalnya, melalui permasalahan dan kerangka konseptual. Selama penelitian berlangsung, peneliti membuat ringkasan, coding, mencatat berbagai dokumen terkait dan sebagainya. Dalam hal ini, reduksi data merupakan bagian yang tidak terpisahkan dari analisis, ini berfungsi untuk lebih menajamkan, mengidentifikasi, mengarahkan dan mengorganisasikan, sehingga penafsiran data mudah dilakukan. Karena itu, dalam mereduksi data, peneliti berupaya mencari dan menemukan data yang benar-benar valid. Jika, terdapat data yang meragukan kebenarannya, maka peneliti melakukan triangulasi.

Penyajian data, merupakan data/informasi yang terkumpul dan tersusun, sehingga memungkinkan peneliti mengambil suatu kesimpulan dalam bentuk, seperti naratif. Ini bertujuan untuk lebih memudahkan peneliti membaca dan mengambil kesimpulan. Dalam hal ini, penyajian data, juga merupakan bagian yang tidak terpisahkan dari analisis, bahkan meliputi pula reduksi data. Proses

${ }^{16}$ Michael Quinn Patton. 1987. Qualitative Evaluation Methods. Beverly Hills: Sage Publication, h. 329 - 331.

${ }^{17}$ Miles Mattew B \& A. Michael Huberman. 1984. Qualitative Data Analysis. New York: Sage Publication, Inc., h. $15-18$. penyajian data, peneliti mengidentifkasi dan mengkategorisasi data kepada beberapa kategori. Setiap kategori data dapat menunjukkan tipologi data berdasarkan rumusan masalah penelitian. Karena itu, dalam proses ini peneliti lebih fokus untuk mengklasifikasi dan mengidentifikasi data/ informasi sesuai dengan tema-tema inti berdasarkan kebutuhan.

Menarik kesimpulan/verifikasi, merupakan bagian dari konfigurasi yang utuh. Dalam kegiatan ini, berbagai kesimpulan telah ditetapkan dalam penelitian yang sedang berlangsung dapat diverifikasi, sehingga kesimpulan tersebut dapat teruji kebenarannya, ini dilakukan oleh peneliti untuk menjaga tingkat validitas. Selain itu, peneliti membuat rumusan proposisi dengan tetap mengutamakan prinsip logika, sehingga dapat dijadikan sebagai temuan penelitian.

\section{HASIL DAN PEMBAHASAN}

\section{Pembinaan Kemampuan dan Keterampilan Guru}

Sesungguhnya faktor kemampuan dan keterampilan merupakan kompetensi guru yang tidak bisa dipisahkan, kerena keduanya memiliki keterkaitan yang saling mendukung dan sangat berperan dalam menentukan kualitas proses pembelajaran yang pada gilirannya dapat lebih meningkatkan kualitas pendidikan di madrasah diniyah sebagaimana yang diharapkan. Dalam hal ini, pada hakekatnya komponen yang menjadi kategori kemampuan mengajar guru, menurut Sudiarto dalam Imron, adalah: (1) kemampuan merencanakan pengajaran, (2) kemampuan melaksanakan pengajaran, dan (3) kemampuan mengevaluasi pengajaran. ${ }^{18}$ Ini berarti, kemampuan mengajar guru merupakan pencerminan penguasaan guru tersebut atas kompetensinya. Sedangkan yang

18 Ali Imron. 1995. Pembinaan Guru di Indonesia. Jakarta: Pustaka Jaya, h. 168 
termasuk komponen keterampilan mengajar guru menurut Usman, yaitu: (1) keterampilan bertanya, (2) keterampilan memberikan penguatan, (3) keterampilan mengadakan variasi, (4) keterampilan menjelaskan informasi, (5) keterampilan membuka dan menutup pembelajaran, (6) keterampilan membimbing diskusi, (7) keterampilan mengelola kelas, dan (8) keterampilan mengajar kelompok kecil dan perorangan. ${ }^{19}$

Mengenai pembinaan kemampuan dan keterampilan mengajar guru, Muchlisin mengemukakan bahwa pada saat ini pengaruh nilai-nilai budayaglobal yang sangat cenderung hedonistik, matrialistik, dan sekularastik yang melanda berbagai aspek kehidupan, terutama di Daerah Istimewa Yogyakarta sebagai salah satu daerah terbesar tujuan wisata, setiap saat anak-anak dipertontonkan berbagai sikap dan perilaku wisatawan asing yang tidak sejalan dengan ajaran-ajaran Islam, khususnya dalam masalah berpakaian, pergaulan bahkan penggunaan obat-obat terlarang.

Kondisi yang demikian ini pendidikan diniyah (madrasah diniyah takmiliyah) semakin meningkatkan kepercayaan masyarakat terhadap pendidikan diniyah. Hal ini mengharuskan setiap guru untuk selalu meningkatkan kemampuannya, terutama berkaitan dengan tugas dan fungsinya sebagai pendidik dan pengajar. Jika tidak, maka guru akan ketinggalan, termasuk santrinya. Karena itu, kemampuan dan keterampian guru dalam mendidik dan mengajar seharusnya senantiasa lebih ditingkatkan "hari ini harus lebih baik dari hari kemarin, jika hari ini sama saja dengan hari kemarin, berarti rugi" ini merupakan prinsip dalam kehidupan yang harus diwujudkan. Hal ini dapat terwujud melalui proses pembelajaran yang dilakukan oleh guru yang memiliki kemampuan dan keterampilan dalam mengajar. Sedangkan kualitas guru yang demikian ini dapat diperoleh melalui pembinaan yang efektif. Sementara itu, selama

19 Uzer Usman. 2010. Menjadi Guru Profesional. Bandung: Remaja Rosdakarya, h. 73 -75. ini efektifitas pembinaan terhadap madrasah diniyah takmiliyah, khususnya pembinaan tentang peningkatan kemampuan dan keterampilan mengajar guru-guru madrasah diniyah takmiliyah masih dipertanyakan, terutama dari kalangan masyarakat yang memasukkan anaknya ke madrasah diniyah takmiliyah. Artinya, madrasah diniyah yang sangat diharapkan oleh umat Islam untuk lebih memperkuat dan memperdalam pendidikan agama Islam bagi anak sulit tercapai, maka di mana lagi umat Islam mendidik anak-anaknya dengan pendidikan agama yang memadai, kalau di pesantren, pesantren sekarang sudah madrasah dan pendidikan agamanya sudah berkurang..$^{20}$ Hal ini menunjukkan, bahwa betapa pentingnya seorang guru untuk mendapatkan pembinaan yang efektif, terutama berkaitan dengan kemampuan dan keterampilan guru dalam mendidik dan mengajar. Ini berarti, bahwa pada hakekatnya pembinaan yang efektif dapat meningkatkan kemampuan dan keterampilan mengajar guru, dan sekaligus dapat memenuhi harapan masyarakat. Sebaliknya, jika pembinaan tidak dapat meningkatkan kemampuan dan keterampilan mengajar guru madrasah diniyah akan membuat masyarakat "kecewa".

Di samping itu, dalam focus group discussion ${ }^{21}$ dari sejumlah pendapat yang berkembang berkaitan dengan pembinaan guru, khususnya "pembinaan kemampuan dan keterampilan mengajar guru", dapat disimpulkan bahwa umumnya peserta diskusi mengemukakan, kegiatan pembinaan kemampuan dan keterampilan mengajar guru sangatlah penting dan strategis dalam meningkatkan kualitas guru, mengingat guruguru di madrasah diniyah cukup banyak tidak berpendidikan sebagai guru, sehingga jika

${ }^{20}$ Hasil wawancara dengan Bapak Muchlisin, Ketua Forum Komunikasi Diniyah Takmiliyah (FKDT) Kota Yogyakarta, tanggal 6 Maret 2014.

${ }^{21}$ FGD dilaksanakan pada tgl 7 Maret 2014, bertempat di Aula Kantor Kementerian Agama Kota Yogyakarta yang dihadiri oleh unsur-unsur dari guru-guru dan Kepala Madrasah Diniyah, tokoh masyarakat, Forum Komunikasi Madrasah Diniyah (FKMD). 
guru-guru tersebut berkualitas dalam proses pembelajaran, maka jelas pada akhirnya pendidikan di madrasah diniyah berkualitas. Karena itu, jika masyaraakat mengahrapkan pendidikan di madrasah diniyah berkualitas, maka terlebih dahulu harus berkualitas adalah "guru-guru madrasa diniyah".

Selama ini, pembinaan guru-guru di madrasah diniyah biasanya dilakukan oleh kepala madrasah diniyah. Karena kepala madrasah diniyah sibuk ceramah di berbagai majelis ta'lim, maka mereka jarang melakukan pembinaan terhadap guru. Kalaupun kepala madrasah diniyah sempat melakukan pembinaan, biasanya hanya berkaitan dengan masalah-masalah administrasi kesiswaan dan keuangan. Sedangkan pembinaan terhadap peningkatan kemampuan dan keterampilan guru dalam mengajar sering tidak dilakukan. Bahkan aktifitas guru yang berkaitan dengan proses pembelajaran sering tidak terpantau, sehingga mereka kurang mengetahui bagaimana tingkat kemampuan dan keterampilan guru dalam proses pembelajaran, khususnya bagi guru-guru yang masih baru, (belum banyak memiliki pengalaman mengajar). Karena guru-guru di madrasah diniyah umumnya berstatus sebagai guru honorer, maka pengurus yayasan tidak dapat menolak permintaan bagi guru yang akan berhenti mengajar, misalnya, karena guru tersebut sibuk dalam pekerjaan lainnya. Sehingga pengurus yayasan berupaya mencari dan mendapatkan guru penggantinya, sebagai akibatnya hampir setiap tahun ada beberapa guru yang tergolong masih baru, jelas guru baru tersebut sangat memerlukan pembinaan, khususnya pembinaan dalam proses pembelajaran.

Sedangkan Kementerian Agama sebagai pihak dari pemerintah yang berkewajiban melakukan pembinaan terhadap madrasah diniyah takmiliyah, khususnya pembinaan tentang peningkatan kemampuan dan keterampilan mengajar guru, selama ini jarang melakukan pembinaan dengan berbagai alasan, khususnya pembinaan kemampuan dan keterampilan mengajar guru. Ada kecenderungan, bahwa mungkin aparat Kementerian Agama belum sepenuhnya menyadari bahwa pembinaan terhadap guru sangat berarti dalam meningkatkan kinerja guru. Meraka biasanya membina guru hanya ketika mereka hadir (memenuhi undangan) di madrasah diniyah di waktu rapat guruguru madrasah diniyah untuk memberi pengarahan, misalnya, pengarahan tentang penggunaan kurikulum madrasah diniyah yang disusun oleh Kementerian Agama. Padahal pembinaan yang semacam ini, tampaknya tidak efektif untuk meningkatkan kemampuan dan keterampilan guru madrasah diniyah. Namun, sesungguhnya Kementerian Agama telah berupaya meningkatkan kemampuan guru madrasah diniyah melalui orientasi, workshop dan pertemuan-pertemuan lainnya. Tapi, pembinan tersebut tidak fokus kepada peningkatan kemampuan dan keterampilan guru dalam mengajar. Selain itu, tidak semua guru-guru madrasah diniyah diundang, hanya guru-guru tertentu saja. Akhirnya kegiatan tersebut, entahlah bagaimana hasilnya.

Uraian di atas menunjukkan, bahwa pengangkatan pejabat Kementerian Agama yang menangani pembinaan madrasah diniyah hendaknya tidak asal-asalan. Tapi, sangat diharapkan pejabat yang pernah belajar (mengenyam pendidikan di madrasah diniyah), sehingga mereka dapat merasakan dan menghayati secara mendalam bagaimana kondisi sesungguhnya guru-guru di madrasah diniyah. Minimal pejabat Kementerian Agama yang menangani pembinaan madrasah diniyah dapat memiliki "komitmen dan kepedulian yang tinggi" terhadap pentingnya pembinaan terhadap peningkatan kemampuan dan keterampilan mengajar guru. Ini ini berarti, bahwa peserta focus group discussion (kepala dan guru-guru madrasah diniyah, tokoh masyarakat, dan pengurus forum komunikasi madsarah diniyah takmiliyah) sangat mengharapkan adanya "profesionalisme" betul-betul menjadi pertimbangan dalam 
mengangkat pejabat Kementerian Agama yang menangani pembinaan madrasah diniyah, khususnya pembinaan peningkatan kemampuan dan keterampilan mengajar guru. Mungkin yang berwenang dalam mengangkat pejabat lupa akan pentingnya kehadiran seorang yang profesional sehingga masalah profesionalisme kurang mendapat perhatian. Memang benar, bagaimana bisa melaksanakan tugas untuk membina guru madrasah diniyah kalau tidak pernah merasakan kehidupan di madrasah diniyah, minimal pernah menjadi santri di madrasah diniyah, bahkan lebih baik lagi jika pernah menjadi guru madrasah diniyah. Aparat Kementerian Agama, seharusnya menyadari bahwa salah satu keberhasilan Kementerian Agama, adalah jika Kementerian Agama dapat membina kemampuan dan keterampilan mengajar guru, sehingga mutu pendidikan di madrasah diniyah dapat lebih berkualitas, sehingga pendidikan keagamaan di madrasah diniyah takmiliyah dapat berperan secara maksimal untuk memperkuat, melengakapi, memperkaya dan memperdalam pendidikan agama Islam pada jalur pendidikan/sekolah formal, sebagaimana amanah yang terkandung dalam keputusan Menteri Agama RI tersebut.

Sedangkan menurut Nurdin selama ini jika masyarakat baik secara perorangan maupun berbentuk yayasan (organisasi keagamaan/ masyarakat) akan mendirikan lembaga pendidikan keagamaan, seperti madrasah diniyah terlebih dahulu harus mendapat izin dari Kementerian Agama. Untuk itu, pihak Kementerian Agama lah yang berkewajiban untuk membina guru-guru madrasah diniyah, jangan hanya mengizinkan pendirian madrasah diniyah, tapi setelahitu seolah-olah tidak peduli lagi, bahkan Nurdin yakin bahwa sampai saat ini masih terdapat sejumlah madrasah diniyah yang belum pernah dikunjungi oleh aparat Kementerian Agama, jika begini kondisinyaa bagaimana melakukan pembinaan yang efektif. Selanjutnya, Nurdin menuturkan, bahwa di DI Yogyakarta ini pendirian madrasah diniyah di luar pondok pesantren, seperti; masjid dan musholla mengalami perkembangan yang sangat menggembirakan. Karena pada akhirakhir ini masyarakat umumnya menginginkan anaknya belajar agama di madrasah diniyah, kalau pagi sekolah di SD atau SMP, bahkan ada dari MI atau MTs, kalau siang sampai sore belajar agama di madrasah diniyah. Karena itu, pada akhir-akhir ini beberapa TPA/ TPQ yang diselenggarakan di masjid atau mushalla berubah menjadi madrasah diniyah karena mengikuti tuntutan dan kebutuhan masyarakat, misalnya; TPA/TPQ Masjid Baitul Amin, setahun yang lalu berubah menjadi Madrasah Diniyah Takmiliyah dengan jenjang pendidikan I'dad, Ula dan Wustha. Tapi, apakah pihak Kementerian Agama memiliki program pembinaan, khususnya pembinaan peningkatan kemampuan guru-guru madrasah diniyah ? Padahal berkembangnya madrasah diniyah di tengah-tengah masyarakat merupakan potensi yang sangat besar tidak hanya bagi umat Islam, tapi juga bagi bangsa Indonesia pada umumnya. Jika pihak Kementerian Agama tidak melakukan pembinaan secara efektif, maka kesempatan emas ini akan hilang begitu saja. Menurut Nurdin, sesungguhnya masyarakat yang mendirikan dan menyelenggarakan madrasah diniyah takmiliyah telah berhasil membuat madrasah diniyah untuk menarik minat masyarakat memasukkan anaknya. Karena itu, menurut Nurdin pihak Kementerian Agama seharusnya mengapresiasi hal ini dengan melakukan pembinaan terhadap guru-guru madrasah diniyah. ${ }^{22}$

Uraian di atas, jika dicermati dengan baik dapat disimpulkan bahwa madrasah diniyah sebagai komponen sistem pendidikan nasional berhak untuk memperoleh pembinaan, sedangkan Kementerian Agama berkewajiban memberikan pembinaan yang efektif, sebagaimana yang dilakukan terhadap satuan atau lembaga pendidikan keagamaan

${ }^{22}$ Hasil wawancara dengan Bapak H. Nurdin tokoh masyarakat dan pemerhati madrasah diniyah, pada tgl. 6 Maret 2014 
Islam lainnya, seperti; pondok pesantren. Namun, tampaknya Nurdin sebagai tokoh masyarakat dan sekaligus sebagai tokoh agama dengan berdasarkan kepada pengamatannya terhadap aktifitas yang dilakukan oleh pihak Kementerian Agama, cenderung meragukan bahwa pihak Kementerian Agama telah melakukan pembinaan secara efektif, khususnya pembinaan terhadap peningkatan kemampuan dan ketarampilan guru-guru madrasah diniyah. Ini berarti, bahwa adanya tokoh masyarakat ini tampak ragu dan tidak puas terhadap pembinaan guru-guru madrasah diniyah, menunjukkan bahwa Kementerian Agama tidak efektif dalam melakukan pembinaan guru-guru madrasah diniyah. Selain itu, faktor yang menunjukkan bahwa Kementerian Agama tidak efektif dalam melakukan pembinaan guru-guru adalah tidak adanya konsistensi dalam melakukan pembinaan guru-guru.

Untuk mengetahui secara langsung, apakah guru-gurumadrasah diniyah takmiliyah memiliki kemampuan dan keterampilan dalam proses pembelajaran, maka peneliti melakukan observasi terhadap guru yang sedang mengajar di kelas. Berdasarkan observasi ${ }^{23}$ terhadap ustadzah Dyah $\mathrm{Tri}^{24}$ yang sedang mengajar Ilmu Hadis di Madrasah Diniyah Takmiliyah Al Qur'an 'Aisyiyah Jatimulyo dapat diketahui bahwa tingkat kemampuan dan keterampilannya dalam mengajar tergolong "baik". Hal ini dapat diketahui dari mulai kemampuan merencanakan proses pembelajaran, melaksanakan pembelajaran dan sampai kepada mengevaluasi proses dan hasil pembelajaran. Demikian juga, telah memiliki keterampilan yang baik dalam proses pembelajaran, dengan sejumlah indikator, antara lain: meningkatkan partisipasi santri dalam kegiatan belajar2014

${ }^{23}$ Hasil observasi yang dilakukan pada tgl. 5 Maret

${ }^{24}$ Dyah Tri (23 tahun), salah seorang ustadzah di Madrasah Diniyah Takmiliyah Al Qur'an 'Aisyiyah Jatimulyo, masih berstatus sebagai mahasiswi Universitas Gajah Mada mengajar, membangkitkan minat dan rasa ingin tahu santri terhadap suatu masalah yang sedang dibicarakan, mengembangkan pola dan cara belajar aktif dari santri, pertanyaannya jelas dan mudah dimengerti oleh santri, melibatkan santri untuk berfikir dengan memecahkan masalah, menganalisis pandangan santri, memberikan respon yang ramah dan menyenangkan sehingga santri percaya diri dan memiliki keberanian untuk menjawab pertanyaan atau bertanya kepada guru, dapat memusatkan perhatian santri pada tujuan atau topik diskusi, memperluas masalah atau urutan pendapat, menganalisis pandangan santri, guru menyebarkan kesempatan kepada santri untuk berpartisipasi aktif dalam diskusi.

Gambarangurudalam proses pembelajaran di atas, menunjukkan bahwa guru tersebut telah memiliki kemampuan dan keterampilan dalam proses pembelajaran dengan indikator, antara lain: dapat memahami dengan baik perasaan santri, mampu dan terampil dalam menggali dan mengangkat berbagi ide yang berkaitan dengan materi pembelajaran, dapat memberi penjelasan dan pengaharahan dengan kritikan-kritikan, namun tetap menyampaikan pujian atau sanjungan kepada santri. Selain itu santri dapat merespon yang pada gilirannya siswa tersebut berinisiatif untuk aktif dalam proses pembelajaran.

Menurut ustadz Sadirin di Madrasah Diniyah Takmiliyah Al Qur'an 'Aisyiyah Jatimulyo ini telah diprogramkan "Pembinaan Ustadz/ahDasardanSyahadah",dalamkegiatan ini termasuk diklat pembinaan peningkatan kemampuan dan keterampilan ustadz/ah dalam mengajar. Kegiatan ini dilaksanakan sebanyak tiga kali dalam setahun dengan tujuan untuk menjaga dan meningkatkan kualitas pendidikan di Madrasah Diniyah Takmiliyah Al Qur'an 'Aisyiyah Jatimulyo. Juga Sadirin menuturkan, bahwa tolak ukur sebuah madrasah diniyah yang berkualitas adalah terletak pada kualitas asatidz/ah yang mempuni dan secara kuantitas mencukupi. 
Untuk itu, program diklat pembinaan peningkatan kemampuan dan keterampilan ustadz/ah dalam mengajar adalah merupakan program "prioritas" di madrasah diniyah ini.

Selanjutnya Sadirin menuturkan, bahwa dari tiga kali program diklat pembinaan ustadz/ ah tersebut tidak semuanya dilakukan dalam bentuk kegiatan pertemuan, seperti; seminar atau workshop. Tapi, di antaranya dilakukan dalam bentuk "studi banding" ke lembagalembaga madrasah diniyah yang dipandang memiliki keunggulan atau keistimewaan, baik dari aspek manajemen, administrasi, sumber keuangan maupun menajemen peningkatan kemampuan dan keterampilan guru. Hasil studi banding tersebut, dapat dijadikan sebagai salah satu bahan (materi) diskusi dalam diklat yang menghadirkan narasumber yang ahli dalam bidangnya.

Begitupun, dalam wawancara Sadirin mengungkapkan bahwa setiap diselenggarakan diklat pembinaan peningkatan kemampuan dan keterampilan ustadz/ah dalam mengajar, semua ustadz/ah madrasah diniyah ini yang berjumlah 14 orang dapat mengikutinya. Acara pembinaan ini setiap kali diselenggarakan berlangsung selama 5 hari (dari pagi sampai sore) tentunya diselang-selingi waktu istirahat untuk makan dan shalat. Nara sumber didatangkan dari Universitas Negeri Yogyakarta (Fakultas Keguruan dan Ilmu Pendidikan) dan Universitas Islam Negeri Sunan Kalijaga (Fakultas Tarbiyah) dengan materi, antara lain: kemampuan merencanakan proses pembelajaran, melaksanakan dan mengevaluasi proses dan hasil pembelajaran dan keterampilan dalam membangkitkan minat dan motivasi santri dan lainnya yang berkaitan dengan keterampilan guru dalam proses pembelajaran. Sedangkan metode, teknik dan pendekatan diklat yang diterapkan adalah "andragogik". ${ }^{25}$

${ }^{25}$ Hasil wawancara dengan ustadz Sadirin Kepala Madrasah Diniyah Takmiliyah Al Qur'an 'Aisyiyah Jatimulyo pada tanggal 5 Maret 2014
Dari hasil wawancara di atas menunjukkan, bahwa adanya ustadzah tersebut memiliki kemampuan dan keterampilan dalam mengajar tergolong "baik", karena inisiatif kepala madrasah diniyah yang mendapat dukungan kuat dari guru-guru dan para pengurus Madrasah Diniyah Takmiliyah Al Qur'an 'Aisyiyah Jatimulyo ini untuk melaksanakan diklat pembinaan ustadz/ah yang sangat efektif, yaitu tiga kali dalam setahun (sekali dalam empat bulan), yaitu setiap catur wulan dengan mendatangkan para ahli dalam bidangnya. Tentunya kegiatan ini sangat baik, namun hampir dapat dipastikan bahwa kegiatan ini menggunakan biaya yang relatif besar. Apakah mampu pengurus madrasah diniyah lainnya ? Dapat diduga pengurus madrasah diniyah lainnya secara ekonomi tidak memiliki kemampuan. Sebab sampai saat ini ternyata hanya di Madrasah Diniyah Takmiliyah Al Qur'an 'Aisyiyah Jatimulyo yang melaksanakan kegiatan pembinaan ustadz/ah dengan biaya sendiri. Ini berarti, bahwa adanya asatidz/ah Madrasah Diniyah Takmiliyah Al Qur'an 'Aisyiyah Jatimulyo dapat memiliki kemampuan dan keterampilan yang baik dalam mengajar, karena melalui pembinaan yang telah diprogramkan dan dianggarkan dengan memadai, bukan hasil pembinaan dari aparat Kementerian Agama.

Begitupun observasi ${ }^{26}$ terhadap ustadz Qoribul Husni yang sedang mengajar Hadis Al Arbain Annawawi di Madrasah Diniyah Pondok Pesantren Al Barokah Tegalrejo dapat diketahui bahwa tingkat kemampuan dan keterampilannya dalam mengajar hanya tergolong "cukup baik". Hal ini dapat diketahui dari mulai kemampuan merencanakan proses pembelajaran, melaksanakan pembelajaran dan sampai kepada mengevaluasi proses dan hasil pembelajaran, masih terdapat beberapa tahapan kadang-kadang belum dapat berlangsung dengan lancar. Begitupun, belum memiliki keterampilan yang baik dalam proses pembelajaran, misalnya dalam

\footnotetext{
${ }^{26}$ Observasi dilakukan pada tgl. 6 Maret 2014
} 
mengajukan pertanyaan kepada santri, pertanyaannya masih kadang-kadang bersayap (bisa mengadung beberapa pengertian), juga pada saat pemebelajaran berlangsung, cenderung belum memiliki kemampuan untuk lebih menggairahkan minat santri untuk memperhatikannya, kadang-kadang perhatiannya hanya tertuju kepada santri tertentu, lebih cenderung bertanya kepada santri yang menurut dia lebih pintar dari teman-temannya.

Gambaran guru dalam proses pembelajaran di atas, menunjukkan bahwa guru tersebut belum memiliki kemampuan dan keterampilan yang tinggi dalam proses pembelajaran dengan indikator, antaralain: belum banyak memahami perasaan santri, masih kurang mampu dan terampil dalam menggali dan mengangkat berbagi ide yang berkaitan dengan materi pembelajaran, kurang memberi penjelasan dan pengaharahan dengan kritikan-kritikan yang menyejukkan santri. Akhirnya santri belum banyak merespon penjelasan guru dan santri masih kurang berinisiatif untuk aktif dalam proses pembelajaran.

Menurut Ustadz Fika Fauzi, S.Si Kepala Madrasah Diniyah Pondok Pesantren Al Barokah, bahwa ustadz Qoribul Husni ini secara resmi belum pernah mendapat pembinaan, khususnya pembinaan peningkatan kemampuan dan keterampilan mengajar guru dari aparat Kementerian Agama. Juga demikian halnya dengan asatidz/ah lainnya, meskipun aparat Kementerian Agama kadangkadang berkunjung ke pondok pesantren ini, tapi secara khusus memberikan pembinaan tentang kemampuan dan keterampilan mengajar guru selama ini belum pernah. Ustadz Qoribul Husni memang pernah mengikuti pembinaan guru, tapi hanya sedikit materinya yang berkaitan dengan peningkatan kemampuan dan keterampilan dalam mengajar. Acara ini dilaksanakan oleh Kantor Wilayah Kementerian Agama Provinsi DI Yogyakarta, pada saat itu ustadz Qoribul Husni diundang bukan sebagai guru madrasah diniyah, tapi sebagai guru Madrasah Tsanawiyah. Selain itu, ustadz Qoribul Husni ini telah memiliki pengalaman mengajar yang sangat memadai. ${ }^{27}$

Hasil observasi dan wawancara di atas, menunjukkan bahwa tingkat kemampuan dan keterampilan mengajar guru di madrasah Diniyah tergolong "baik" dapat diperoleh melalui pembinaan yang telah diprogramkan secara memadai dan dilaksanakan dengan biaya sendiri dan diduga pembinaan tersebut menggunakan biaya yang relatif besar, apalagi sebanyak tiga kali dalam setahun. Apakah setiap madrasah diniyah di Kota Yogyakarta secara ekonomi memiliki kemampuan yang memadai untuk melakukan pembinaan kemampuan dan ketarampilan mengajar guru dengan biaya sendiri ? Jika tidak, maka hampir dapat dipastikan bahwa umumnya guru-guru madrasah diniyah belum pernah secara intensif memperoleh pembinaan yang khusus berkaitan dengan kemampuan dan keterampilan mengajar guru, padahal pembinaan yang semacam ini sangat berperan dalam menentukan tingkat kemampuan dan keterampilan mengajar guru dan pada akhirnya dapat meningkatkan kualitas pendidikan di madrasah diniyah.

Berdasarkan uraian di atas, dapat ditarik kesimpulan bahwa sesungguhnya guru-guru (asatidz/ah) madrasah diniyah di Kota Yogyakarta meskipun sebagian besar tidak memiliki latar belakang pendidikan keguruan dan ilmu pendidikan, tapi ternyata umumnya telah memiliki bibit-bibit kompetensi pedagogik dan kompetensi professional, sehingga dalam menjalankan tugasnya sebagai pengajar dan pendidik dapat memiliki kemampuan dan keterampilan yang tergolong "baik" dalam proses pembelajaran. Hal ini dapat dilihat pada guru Madrasah Diniyah Takmiliyah Al Qur'an 'Aisyiyah Jatimulyo yang setiap tahun secara terprogram mengikuti diklat peningkatan

\footnotetext{
${ }^{27}$ Hasil wawancara dengan Ustadz Fika Fauzi Kepala Madrasah Diniyah Pondok Pesantren Al Barokah Blunyahrejo Karangwaru Tegalrejo, pada tanggal 5 Maret 2014
} 
kemampuan dan keterampilan mengajar. Artinya, guru Madrasah Diniyah Takmiliyah Al Qur'an 'Aisyiyah ini jauh lebih baik dalam hal kemampuan dan keterampilan mengajar, jika dibanding dengan guru Madrasah Diniyah Pondok Pesantren Al Barokah yang tidak memiliki program diklat peningkatan kemampuan dan keterampilan guru mengajar

Namun, bibit-bibit kompetensi pedagogik dan kompetesnis professional tersebut kurang mendapat siraman air dan pupuk berupa pembinaan peningkatan kemampuan dan keterampilan mengajar. Akibatnya kompetensi pedagogik dan kompetesnis professional guru tersebut bagaikan tanaman yang tumbuh di tanah gersang, kurang berperan dalam menentukan kualitas pendidikian di madrasah diniyah. Hal ini dapat berimplikasi kepada masih rendahnya kualitas pendidikan di madrasah diniyah, sehingga pendidikan di madrasah diniyah dari sejak dulu sampai sekarang dan bahkan sampai pada masa yang akan datang seakan-akan berjalan di tempat. Pada hal, disadari atau tidak sesungguhnya pendidikan di madrasah diniyah adalah merupakan "pondasi pembentukan karakter" bangsa Indonesia.

Di samping itu, melalui wawancara ${ }^{28}$ dengan Kasi Pendidikan Diniyah dan Pondok Pesantren Kantor Kementerian Agama Kota Yogyakarta mengemukakan, bahwa madrasah diniyah di Kota Yogyakarta mengalami perkembangan yang cukup baik, ini dibuktikan dengan antusias masyarakat mendirikan dan menyelenggarakan madrasah diniyah, sehingga jumlah madrasah diniyah yang terdaftar di Kantor Kementerian Agama Kota Yogyakarta sampai tahun 2014 ini dapat mencapai 28 satuan pendidikan. Beliau mengakui bahwa selama ini pembinaan yang dilakukan oleh pihak Kementerian Agama belum optimal. Selama ini pembinaan yang telah dilakukan, antara lain berkaitan dengan penggunakan kurikulum yang disusun oleh

${ }^{28}$ Wawancara dilakukan pada tanggal 7 Maret 2014
Kementerian Agama. Juga, dalam wawancara Kasi Pendidikan Diniyah dan Pondok Pesantren mengemukakan:

1. Untuk peningkatan peran lembaga pendidikan diniyah, maka dilakukan penataan dan peran-peran masing-masing struktur dalam kelembagaan tersebut.

2. Monitoring dan supervisi terhadap penggunaan kurikulum madrasah diniyah yang disusun oleh Kementerian Agama.

3. Memperhatikan masalah kesejahteraan guru/ustadz madrasah diniyah.

4. Penelusuran minat dan bakat santri terkait dengan pemberian beasiswa

5. Metode pembelajaran, perlu adanya pembinaan metodologi pembelajaran yang menarik

6. Sarana dan fasilitas pendidikan di madrasah diniyah masih banyak mengalami kekurangan, ini penting dilengkapi untuk menunjang keberhasilan pendidikan di madrasah diniyah.

7. Sistem pengelolaan madrasah diniyah, masihterbatas terutama dalam menajemen organisasi/lembaga.

Apabila memperhatikan hasil wawancara dengan Kasi Pendidikan Diniyah dan Pondok Pesantren Kantor Kementerian Agama Kota Yogyakarta di atas, dapat diduga bahwa kegelisahan masyarakat terhadap kualitas pendidikan di madrasah diniyah belum menemukan titik terang. Artinya, masalah pembinaan kemampuan dan keterampilan mengajar guru di madrasah diniyah belum tersentuh dengan efektif oleh pihak yang berkewajiban melakukan pembinaan, yaitu pihak aparat Kementerian Agama. Ini berarti, bahwa kualitas pendidikan keagamaan di madrasah diniyah yang sangat dirindukan oleh masyarakat masih jauh dari kenyataan. 


\section{PENUTUP}

\section{Kesimpulan}

Pertama, pembelajaran merupakan suatu proses yang kompleks dan melibatkan berbagai aspek yang saling berkaitan. Karena itu, untuk mewujudkan pembelajaran yang berkualitas diperlukan berbagai kemampuan dan keterampilan mengajar guru. Hal ini dapat terwujud melalui pembinaan yang efektif dari bebagai pihak, khususnya pihak Kementerian Agama.

Kedua, aparat Kementerian Agama Kota Yogyakarta kurang efektif melakukan pembinaan secara khusus dan intensif terhadap peningkatan kemampuan dan keterampilan guru-guru madrasah diniyah. Ini dapat diketahui dari adanya kurang kepuasan guru-guru terhadap pembinaan yang dilakukan oleh Kementerian Agama. Hal ini dapat terjadi, karena Kementerian Agama cenderung belum memiliki target untuk lebih meningkatkan kemampuan dan keterampilan guru mengajar, sebagai akibatnya kurang memprioritaskan pembinaan peningkatan kemampuan dan keterampilan mengajar guru madrasah diniyah.

Ketiga, guru yang telah memiliki kemampuan dan keterampilan mengajar yang memadai diperoleh dari hasil inisiatif para kepala, guru-guru yang mendapat dukungan kuat dari pengurus yayasan untuk melaksanakan diklat tentang "pembinaan guru" dengan biaya sendiri. Hal ini, berarti bahwa kalau seandainya Kementerian Agama secara efektif telah melakukan pembinaan kemampuan dan keterampilan guru mengajar, maka paling tidak sebagian besar guru-guru madrasah diniyah dapat memiliki kemampuan dan keterampilan yang memadai.

\section{Rekomendasi}

Diharapkan kepada Ditjen Pendidikan Islam, Direktorat Pendidikan Diniyah dan Pondok Pesantren, Kantor Wilayah
Kementerian Agama Provinsi DI Yogyakarta, Bidang Pendidikan Diniyah dan Pondok Pesantren, Kantor Kementerian Agama Kota Yogyakarta, Seksi Pendidikan Diniyah dan Pondok Pesantren untuk lebih memprioritas pembinaan kemampuan dan keterampilan mengajar guru-guru madrasah diniyah. Sebab, guru yang memiliki kemampuan dan keterampilan dalam proses pembelajaran dapat meningkatkan kualitas pendidikan di madrasah diniyah. Jika tidak, maka madrasah diniyah takmiliyah yang diselengggarakan untuk melengkapi, memperkaya dan memperdalam pendidikan agama Islam di sekolah-sekolah formal sulit terwujud.

\section{SUMBER BACAAN}

Alwasilah, A. Chaedar (2003): Pokoknya Kualitatif. Jakarta: Dunia Pustaka Jaya

Bidang Pendidikan Diniyah dan Pesantren Kanwil Kementerian Agama Provinsi D. I Yogyakarta, tahun 2014.

Culhane, Goodall M \& B (1991): Teaching Strategies for a Clever Country. Australia: Association for the Gifted Talented.

Danim, Sudarwan (1994): Tranformasi Sumber Daya Manusia. Jakarta: Bumi Aksara.

Feigenbaum, Armand (1989): Total Quality Control. London: McGraw Hill

Garvin, David A (2000): Learning in Action. Boston: Harvard Business Press.

Gay. L. R (1987): Educational Research: Competencies for Analysis and Application. Columbus: Marril Publishing Company

Glaser \& Anselm L. Strauss, Barney (1980): The Discovery of Grounded Theory. New York: Aldine Publishing Company.

Hamalik, Oemar (2009): Pendidikan Guru Berdasarkan Pendekatan Kompetensi. Jakarta: Bumi Aksara.

Imron, Ali (1995): Pembinaan Guru di Indonesia. Jakarta: Pustaka Jaya. 
Moleong, Lexy J (2004): Metodologi Penelitian Kualitatif. Bandung: Remaja Rosdakarya.

Michael Huberman, Miles Mattew B \& A. (1984): Qualitative Data Analysis. New York: Sage Publication, Inc.

Patton, Michael Quinn (1987): Qualitative Evaluation Methods. Beverly Hills: Sage Publication.

Peraturan Menteri Agama RI Nomor 13 Tahun 2014 tentang Pendidikan Keagamaan Islam.

Prawirosentono, Sujadi (1999): Kebijakan Kinerja Karyawan: Kiat Membangun Orga- nisasi Kompetetif Menjelang Perdagangan Bebas Dunia. Yogyakarta: BPFE.

Sardiman, AM (1996): Interaksi dan Motivasi Belajar Mengajar. Jakarta: Rajawali.

Usman, Uzer (2010): Menjadi Guru Profesional. Bandung: Remaja Rosdakarya.

Wijaya dan Tabrani Rusyan (1992): Profesionalisme Tenaga Kependidikan. Bandung: Nine Karya Jaya. 